Doi: HTTPS://DOI.ORG/10.23910/IJEP/2019.6.2.0298

\title{
Socio-economic Status of Apple Orchardists in Shimla District of Himachal Pradesh
}

\author{
Bharti", P. K. Mahajan, R. K. Gupta, Ashu Chandel and Ankita
}

Dept. of Basic Sciences, Dr Y S Parmar University of Horticulture and Forestry, Nauni, Solan, Himachal Pradesh (173 230), India

\author{
Corresponding Author \\ Bharti \\ e-mail: bhartibhardwaj69@gmail.com
}

\author{
Article History \\ Article ID: IJEP0298 \\ Received in 31 $1^{\text {st }}$ March, 2019 \\ Received in revised form $05^{\text {th }}$ May, 2019 \\ Accepted in final form 15 $15^{\text {th }}$ May, 2019
}

\begin{abstract}
In this paper an attempt was made to study the socio-economic status of apple orchardists of Shimla district of Himachal Pradesh. Multistage sampling was employed for selection of respondents. Primary data on demographic features (family size, age, education, and occupation), economic parameters (land inventory, livestock, cropping pattern etc), yield etc. were collected on well designed pre-tested schedules and tabular analysis was used to examine socio-economic status of the apple orchardists.
\end{abstract}

Keywords: Apple, Himachal Pradesh, socio-economic status

\section{Introduction}

Apple is the most important temperate fruit crop of North Western Indian Himalayan region. In India, apple is largely cultivated in Jammu and Kashmir, Himachal Pradesh and Uttarakhand. Captain AA Lee established first apple orchard in Himachal Pradesh around 1860. Although, history of commercial cultivation of apple in Himachal Pradesh is only a century old, it has made rapid strides in terms of area and production of apples. In, Himachal Pradesh, apple is cultivated in Shimla, Kullu, Kinnaur, Mandi, Sirmaur and Chamba districts. Apple plays an important role in socio-economic transformation of rural masses in the state. Socio-economic survey gives an idea of the conditions under which growers operate. The land utilization pattern, cropping pattern etc give the idea of extent of area that farmers put under actual use. Also, the study of socio-economic status helps in identifying the adaptive capacity of the individuals or communities based on the characteristics like education, economic status, gender, experience, training undergone, access to information etc., and play a vital role in understanding their mode of farming in a keen manner. Keeping this in mind, an attempt was made to study the socio-economic status of apple orchardists with respect to production and marketing of apple crop.

\section{Materials and Methods}

Shimla district was purposely selected due to its highest concentration of apple plantation. The district lies between the longitude $77.00^{\circ}$ and $78.19^{\circ} \mathrm{E}$ and latitude $30.45^{\circ}$ and $31.44^{\circ} \mathrm{N}$. Multistage random sampling technique was employed for the selection of units. In first instance, a complete list of development blocks of Shimla district was prepared from the record of the concerned revenue office. The entire sampling plan consists of four stages. In the first stage, four blocks namely Rohru, Jubbal-Kotkhai, Theog and Narkanda were selected randomly (Figure 1). In second stage, a list of panchayats falling in the selected blocks was prepared and from each block $30 \%$ of panchayats was selected. In third stage, a complete list of villages falling under the selected panchayat was prepared and from each panchayat $30 \%$ villages was selected and finally 400 respondents were selected through a twostep approach as suggested by Stein (1945) and Cox (1952).



Figure 1: Selection of the Study Site

From selected respondents, primary data on demographic features (family size, age, education, and occupation), economic parameters (land inventory, livestock, cropping pattern etc), yield, marketable or marketed surplus, were collected on well designed pre-tested schedules by adopting a personal interview method from the selected households. To meet out the requirements of the study objectives, tabular analysis, averages, \%ages, were computed. Simple tabular analysis was used to examine socio-economic status 
of the growers. 400 selected farmers were divided into four categories according to the size of their land holdings, viz., marginal (<1.00 ha), small (1.00 -2.00 ha), semi-medium (2.00$4.00 \mathrm{ha}$ ) and medium farmers (>4.00 ha). The dependency ratio and sex ratio were calculated using the following formulas:

Dependency Ratio=(Number of dependents in a family/ Total workers in the family) $\times 100$

Sex Ratio=(Number of females in a family/ Number of males in a family) $\times 1000$

Singh et al. (1990) examined the economics of apple production in Himachal Pradesh. Sheikh and Tripathi (2013) conducted a survey to study the socio-economic conditions of apple growers of Kashmir valley. Kashyap and Guleria
(2015) carried out a study with the objective to determine the socio-economic status of growers involved and how different socio-economic factors influence production in Mandi district of Himachal Pradesh. Panwar (2011) reported that apple production in Himachal Pradesh is an impending crisis for the farmers. As $90 \%$ of the apple orchardists are from poor and marginal peasant class based on the extent of land holding. The inherent cause of this crisis is the nature of land holding pattern in addition to the deteriorating quality of land.

\section{Results and Discussion}

Shimla district was purposely selected as this area is ideally suited for the cultivation of apple and other fruits. The important facilities available in the study area and their distance from households have been given in Table 1.

\begin{tabular}{llcccccc}
\hline \multicolumn{6}{l}{ Table 1: Distance between village and various important facilities available in the study area } \\
\hline Category & $\begin{array}{l}\text { Distance } \\
\text { (Kms) }\end{array}$ & Road & $\begin{array}{c}\text { Post } \\
\text { office }\end{array}$ & Bank & $\begin{array}{c}\text { BDO } \\
\text { office }\end{array}$ & $\begin{array}{c}\text { Cooperative } \\
\text { market }\end{array}$ & $\begin{array}{c}\text { Computer } \\
\text { centre }\end{array}$ \\
\hline Marginal & Upto 1 & $46(22.00)$ & $15(7.18)$ & $12(5.74)$ & $2(0.96)$ & $7(3.35)$ & $8(3.83)$ \\
& 1 to 2 & $34(16.27)$ & $64(30.62)$ & $28(13.40)$ & $11(5.26)$ & $16(7.66)$ & $27(12.92)$ \\
& 2 to 3 & $30(14.35)$ & $50(23.92)$ & $38(18.18)$ & $10(4.78)$ & $11(5.26)$ & $23(11.00)$ \\
& 3 to 4 & $47(22.49)$ & $28(13.40)$ & $17(8.13)$ & $6(2.87)$ & $12(5.74)$ & $32(15.31)$ \\
Small & 4 and above & $52(24.88)$ & $52(24.88)$ & $114(54.55)$ & $180(86.12)$ & $163(77.99)$ & $119(56.94)$ \\
& Upto 1 & $27(22.13)$ & $27(22.13)$ & $9(7.38)$ & $1(0.82)$ & $1(0.82)$ & $6(4.92)$ \\
& 1 to 2 & $27(22.13)$ & $35(28.69)$ & $22(18.03)$ & $7(5.74)$ & $12(9.84)$ & $19(15.57)$ \\
& 2 to 3 & $19(15.57)$ & $11(9.02)$ & $6(4.92)$ & $7(5.74)$ & $1(0.82)$ & $12(9.84)$ \\
& 3 to 4 & $20(16.39)$ & $16(13.11)$ & $16(13.11)$ & $3(2.46)$ & $5(4.10)$ & $12(9.84)$ \\
& 4 and above & $29(23.77)$ & $33(27.05)$ & $69(56.56)$ & $104(85.25)$ & $103(84.43)$ & $73(59.84)$ \\
& Upto 1 & $12(22.22)$ & $18(33.33)$ & $10(18.52)$ & $5(9.26)$ & $5(9.26)$ & $6(11.11)$ \\
& 1 to 2 & $6(11.11)$ & $5(9.26)$ & $3(5.56)$ & $1(1.85)$ & $2(3.70)$ & $2(3.70)$ \\
& 2 to 3 & $8(14.81)$ & $3(5.56)$ & $5(9.26)$ & $1(1.85)$ & $3(5.56)$ & $3(5.56)$ \\
& 3 to 4 & $11(20.37)$ & $16(29.63)$ & $15(27.78)$ & $5(9.26)$ & $3(5.56)$ & $16(29.63)$ \\
& 4 and above & $17(31.48)$ & $12(22.22)$ & $21(38.89)$ & $42(77.78)$ & $41(75.93)$ & $27(50.00)$ \\
& Upto 1 & $4(26.67)$ & $6(40.00)$ & $3(20.00)$ & $1(6.67)$ & $1(6.67)$ & $1(6.67)$ \\
& 1 to 2 & $5(33.33)$ & $1(6.67)$ & $2(13.33)$ & $1(6.67)$ & $2(13.33)$ & $2(13.33)$ \\
& 2 to 3 & $1(6.67)$ & $2(13.33)$ & $1(6.67)$ & $1(6.67)$ & $1(6.67)$ & $6(40.00)$ \\
& 3 to 4 & $2(13.33)$ & $1(6.67)$ & $2(13.33)$ & $2(13.33)$ & $2(13.33)$ & $2(13.33)$ \\
& 4 and above & $3(20.00)$ & $5(33.33)$ & $7(46.67)$ & $10(66.67)$ & $9(60.00)$ & $4(26.67)$ \\
\hline
\end{tabular}

Values in parenthesis are $\%$ of respondents in each category

\subsection{Socio-economic profile of the apple orchardists}

The socio-economic characteristics of the farmer affect the organization and management of farm as well as the production and market supply to a medium extent. Therefore, it is necessary to have a broad understanding of social and economic profile of the households who have been actually engaged in apple growing.

\subsection{Size of sampled orchardist's family}

The size of the family and workforce among growers are the important factors influencing the apple enterprise, which happen to be the family based occupation at the village level. The distribution of sampled households has been presented in Table 2. The table revealed that the average size of family was 5.06 at overall level. Majority of households had 4 to 
Table 2: Distribution of sampled household according to family size

\begin{tabular}{lccccc}
\hline Category & Family & \multicolumn{4}{c}{ Family having members } \\
\cline { 3 - 6 } & size & 1 to 3 & 4 to 6 & 7 to 9 & $\begin{array}{c}10 \text { and } \\
\text { above }\end{array}$ \\
\hline Marginal & 4.67 & 61 & 121 & 20 & 7 \\
Small & 5.11 & 19 & 81 & 18 & 4 \\
Semi-medium & 5.80 & 8 & 35 & 7 & 4 \\
Medium & 7.53 & 2 & 5 & 4 & 4 \\
Overall & 5.06 & 90 & 242 & 49 & 19 \\
\hline
\end{tabular}

6 members in the family in all categories. Category wise distribution of workers of sampled growers is presented in Table 3.

Table 3: Category wise distribution of workers of sampled growers

\begin{tabular}{lccccc}
\hline Category & $\begin{array}{l}\text { Family } \\
\text { size }\end{array}$ & $\begin{array}{c}\text { Average } \\
\text { No. of } \\
\text { active } \\
\text { workers }\end{array}$ & $\begin{array}{c}\text { \% of total } \\
\text { family } \\
\text { size }\end{array}$ & $\begin{array}{c}\text { Depen- } \\
\text { dency } \\
\text { ratio }\end{array}$ & $\begin{array}{c}\text { Sex } \\
\text { ratio }\end{array}$ \\
\hline Marginal & 4.67 & 2.88 & 61.67 & 0.62 & 817.50 \\
Small & 5.11 & 3.11 & 60.86 & 0.64 & 928.79 \\
S e m i - & 5.80 & 3.33 & 57.41 & 0.73 & 920.25 \\
medium & & & & & \\
Medium & 7.53 & 4.53 & 60.16 & 0.66 & 915.25 \\
Overall & 5.06 & 3.01 & 59.49 & 0.68 & 878.48 \\
\hline
\end{tabular}

\subsection{Educational status}

Cultivation of apple needs a special attention for scientific management of the farm, acquiring the knowledge of different modern inputs and for techniques of production. For this, education becomes an important parameter for every farm family. Keeping in view, the educational status of the family members, for different categories of the farms has been analyzed and presented in Table 4. Majority of farmers were intermediate in all categories in study area.

\subsection{Occupational distribution of the head of the family}

Occupational distribution of the head of the family is very important in determining the economic status of the family. It is assumed that more developed is the area, the more diversified the employment pattern and same would result in increased income to the household. The occupational structure of farm family members is given in Table 5 . It is noted from the table that agriculture is the main occupation of the people as more than $70 \%$ of work force in Himachal Pradesh practice farming. $71.50 \%$ of sampled farmers practiced agriculture, $14.00 \%$ served the government, 8.75 $\%$ engaged in their own business at overall level. However, the main occupation in all farmer categories was agriculture.
Table 4: Distribution of sampled family head according to their educational status

\begin{tabular}{lccccc}
\hline Category & Marginal & Small & $\begin{array}{c}\text { Semi- } \\
\text { medium }\end{array}$ & $\begin{array}{c}\text { Me- } \\
\text { dium }\end{array}$ & $\begin{array}{c}\text { Over- } \\
\text { all }\end{array}$ \\
\hline Illiterate & 17 & 13 & 15 & 5 & 50 \\
& $(8.13)$ & $(10.66)$ & $(27.78)$ & $(33.33)$ & $(12.50)$ \\
Primary & 52 & 16 & 10 & 3 & 81 \\
& $(24.88)$ & $(13.11)$ & $(18.52)$ & $(20.00)$ & $(20.25)$ \\
Middle & 30 & 13 & 4 & 1 & 48 \\
& $(14.35)$ & $(10.66)$ & $(7.41)$ & $(6.67)$ & $(12.00)$ \\
Matric or & 88 & 61 & 17 & 3 & 169 \\
Interme- & $(42.11)$ & $(50.00)$ & $(31.48)$ & $(20.00)$ & $(42.25)$ \\
diate & & & & & \\
Graduate & 14 & 17 & 7 & 2 & 40 \\
& $(6.70)$ & $(13.93)$ & $(12.96)$ & $(13.33)$ & $(10.00)$ \\
Post & 8 & 2 & 1 & 1 & 12 \\
Graduate & $(3.83)$ & $(1.64)$ & $(1.85)$ & $(6.67)$ & $(3.00)$ \\
\hline
\end{tabular}

Table 5: Occupation of the family member in the study area

\begin{tabular}{lccccc}
\hline Category & Marginal & Small & $\begin{array}{c}\text { Semi- } \\
\text { medium }\end{array}$ & $\begin{array}{c}\text { Me- } \\
\text { dium }\end{array}$ & $\begin{array}{c}\text { Over- } \\
\text { all }\end{array}$ \\
\hline Agricul- & 157 & 87 & 34 & 8 & 286 \\
ture & $(75.12)$ & $(71.31)$ & $(62.96)$ & $(53.33)$ & $(71.50)$ \\
Govern- & 21 & 22 & 9 & 4 & 56 \\
ment & $(10.05)$ & $(18.03)$ & $(16.67)$ & $(26.67)$ & $(14.00)$ \\
service & & & & & \\
Business & 18 & 8 & 7 & 2 & 35 \\
& $(8.61)$ & $(6.56)$ & $(12.96)$ & $(13.33)$ & $(8.75)$ \\
Others & 13 & 5 & 4 & 1 & 23 \\
& $(6.22)$ & $(4.10)$ & $(7.41)$ & $(6.67)$ & $(5.75)$ \\
\hline
\end{tabular}

\subsection{Size of land holding}

Size of the land holding directly affect the income, consumption, saving and investment of land owning households. Therefore, category wise distribution of land holdings of apple orchardists was worked out and is presented in Table 6.

\subsection{Cropping pattern}

Cropping pattern means the proportion of area under various crops at a point of time. The crop statistics published by the governments are used to denote the cropping pattern. Cropping pattern is, however, a dynamic concept as it changes over space and time. The cropping pattern system should provide enough food for the family, fodder for cattle and generate sufficient cash income for domestic and cultivation expenses. The cropping pattern adopted in any region depends mainly on soil, altitude, microclimate, availability of resources and management factors etc. This reflects the future scope of each crop along with the tentative requirements of the inputs for different crops. Hence, the cropping pattern of sampled farms was examined and is presented in Table 7. 


\begin{tabular}{lccccc}
\hline \multicolumn{7}{l}{ Table 6: Land use pattern of sampled household in the study area (ha) } \\
\cline { 2 - 5 } Particulars & Marginal & Small & Semi-medium & Medium & \\
\cline { 2 - 5 } & 0.57 & 1.20 & 2.15 & 2.98 & 1.06 \\
\hline Area under apple & 0.02 & 0.03 & 0.15 & 0.40 & 0.05 \\
Area under other fruits & 0.23 & 0.41 & 0.47 & 0.67 & 0.33 \\
Area under crops & 0.03 & 0.13 & 0.22 & 0.26 & 0.09 \\
Area under vegetables & 0.04 & 0.24 & 0.74 & 1.13 & 0.23 \\
Pastures or Ghasnies & 0.61 & 1.36 & 2.61 & 5.07 & 1.28 \\
Total holding & & & & & \\
\hline
\end{tabular}

Table 7: Cropping pattern and average yield in the study area (q ha-1)

\begin{tabular}{|c|c|c|c|c|c|}
\hline \multirow[t]{2}{*}{ Particulars } & \multicolumn{4}{|c|}{ Category } & \multirow{2}{*}{$\begin{array}{c}\text { Over- } \\
\text { all }\end{array}$} \\
\hline & $\begin{array}{l}\text { Mar- } \\
\text { ginal }\end{array}$ & Small & $\begin{array}{c}\text { Semi- } \\
\text { medium }\end{array}$ & $\begin{array}{l}\text { Me- } \\
\text { dium }\end{array}$ & \\
\hline \multicolumn{6}{|l|}{ Cereals } \\
\hline Wheat & 18.87 & 18.98 & 19.87 & 19.99 & 19.08 \\
\hline Maize & 14.98 & 15.76 & 13.77 & 12.44 & 14.96 \\
\hline Pluses & 17.65 & 13.45 & 12.65 & 12.67 & 15.51 \\
\hline \multicolumn{6}{|l|}{ Vegetables } \\
\hline Peas & 93.78 & 92.76 & 95.78 & 98.83 & 93.93 \\
\hline Tomato & 187.98 & 193.64 & 199.76 & 197.89 & 191.67 \\
\hline Beans & 81.87 & 88.83 & 80.66 & 89.87 & 84.13 \\
\hline $\begin{array}{l}\text { Onion and } \\
\text { garlic }\end{array}$ & 96.78 & 93.74 & 96.12 & 90.25 & 95.52 \\
\hline Cabbage & 155.17 & 145.47 & 180.67 & 176.56 & 156.46 \\
\hline Cauliflower & 132.67 & 150.63 & 127.87 & 183.89 & 139.42 \\
\hline Bhindi & 32.89 & 25.74 & 33.89 & 35.98 & 30.96 \\
\hline Capsicum & 74.15 & 70.67 & 72.87 & 74.99 & 72.95 \\
\hline Brinjal & 50.10 & 49.01 & 50.59 & 59.89 & 55.99 \\
\hline \multicolumn{6}{|l|}{ Fruit crops } \\
\hline Apple & 169.11 & 173.29 & 156.96 & 114.57 & 161.49 \\
\hline Plum & 12.60 & 13.34 & 13.56 & 13.89 & 13.00 \\
\hline Peach & 3.90 & 3.45 & 3.87 & 3.22 & 3.73 \\
\hline Apricot & 3.22 & 1.98 & 1.78 & 1.77 & 2.59 \\
\hline Pear & 31.24 & 31.90 & 33.67 & 33.92 & 31.87 \\
\hline Cherry & 4.90 & 5.30 & 5.66 & 5.82 & 5.16 \\
\hline Kiwi & 2.11 & 2.78 & 5.93 & 6.13 & 2.98 \\
\hline $\begin{array}{l}\text { Pomegran- } \\
\text { ate }\end{array}$ & 1.12 & 0.99 & 0.97 & 1.23 & 1.06 \\
\hline Persimmon & 1.32 & 1.87 & 1.94 & 1.97 & 1.60 \\
\hline Walnut & 0.65 & 0.78 & 0.56 & 0.88 & 0.69 \\
\hline
\end{tabular}

This table revealed that there was not much difference in the productivity level of different crops under various categories of farm.

\subsection{Livestock inventory}

The productivity of apple is affected by the use of farmyard manure. The quantum of farmyard manure on the farm depends upon the number of animals reared by the cultivator households. Keeping in view, data on livestock for each household was collected and same has been presented in Table 8.

\subsection{Marketable and marketed surplus}

Apple is one of the fruits of the state mainly grown for the market. Only a small proportion is kept for home consumption, gifts and such other purposes (Table 9).

\subsection{Post harvest losses in apple}

The apple production has increased tremendously in Himachal Pradesh but orchards are still being managed on conventional lines which result in post-harvest losses due to improper handling, storage, transportation and distribution system. The fruits wasted in transit from orchards to consumers represent a significant loss (Table 10). A substantial quantity of production is subjected to post-harvest losses at various stages of marketing. To improve the marketing system, it is essential to create awareness among the growers, farm workers and managers and traders about the extent of these losses and their economic consequences. The over ripened phase, climatic conditions and effect of rodents, insects, pests were the most important causes of losses during harvesting and assembling. Other factors like scarcity of skilled labour, rough handling at farm and in transit, short notice to transportation etc are other causes of post harvest losses. Market loss was mostly due to space problem, delay in auction or unacceptance of produce by commission agent or wholesaler. Prasher et al (2000) also analyzed the postharvest losses of apple in Himachal Pradesh with the specific objectives to estimate quantitative and qualitative losses in different packaging at various stages of post-harvest handling of apple. Gangwar and Singh (2007) also estimated the post - harvest losses in kinnow in Punjab during 2004-05. 


\begin{tabular}{|c|c|c|c|c|c|c|c|c|}
\hline \multirow[t]{2}{*}{ Particulars } & \multicolumn{4}{|c|}{ Number of household having livestock } & \multicolumn{4}{|c|}{ Average number of livestock } \\
\hline & Cow & Sheep & Goat & Ox & Cow & Sheep & Goat & Ox \\
\hline Marginal & $184(88.04)$ & $32(15.31)$ & $41(19.62)$ & $23(11.00)$ & 1.52 & 10.22 & 3.34 & 2.13 \\
\hline Small & $108(88.52)$ & $18(14.75)$ & $25(20.49)$ & $23(18.85)$ & 1.74 & 2.44 & 2.80 & 2.04 \\
\hline Semi-medium & $51(94.44)$ & $13(24.07)$ & $18(33.33)$ & $14(25.92)$ & 2.41 & 3.76 & 2.77 & 2.21 \\
\hline Medium & $14(93.33)$ & $1(6.67)$ & $6(40.00)$ & $5(33.33)$ & 2.21 & 2.00 & 2.50 & 2.00 \\
\hline Overall & 375 (89.25) & $64(16.00)$ & $90(22.50)$ & 65 (16.75) & 1.74 & 6.59 & 3.02 & 2.10 \\
\hline
\end{tabular}

Table 9: Total production, family requirements and marketed surplus of apple in study area (q farm ${ }^{-1}$ )

\begin{tabular}{lcccccc}
\hline Category & Area (ha) & Total production & Home consumption & Kind payment & Gift & Marketed surplus \\
\hline Marginal & 0.57 & $4.79(100.00)$ & $0.03(0.68)$ & $0.01(0.16)$ & $0.01(0.21)$ & $4.74(98.95)$ \\
Small & 1.20 & $10.37(100.00)$ & $0.05(0.48)$ & $0.01(0.13)$ & $0.02(0.18)$ & $10.29(99.20)$ \\
Semi-medium & 2.15 & $16.89(100.00)$ & $0.06(0.36)$ & $0.02(0.10)$ & $0.03(0.18)$ & $16.78(99.36)$ \\
Medium & 2.98 & $21.89(100.00)$ & $0.09(0.39)$ & $0.03(0.14)$ & $0.03(0.15)$ & $21.75(99.33)$ \\
Overall & 1.06 & $8.77(100.00)$ & $0.04(0.50)$ & $0.01(0.13)$ & $0.02(0.19)$ & $8.69(99.18)$ \\
\hline
\end{tabular}

Table 10: Post harvest losses during storage, transportation and marketing of apple in study area

\begin{tabular}{lccccccc}
\hline Particulars & $\begin{array}{c}\text { During } \\
\text { harvesting }\end{array}$ & $\begin{array}{c}\text { During } \\
\text { assembling }\end{array}$ & $\begin{array}{c}\text { During grading and } \\
\text { packaging }\end{array}$ & $\begin{array}{c}\text { During } \\
\text { storage }\end{array}$ & $\begin{array}{c}\text { Transportation } \\
\text { Losses in the } \\
\text { market }\end{array}$ & Total \\
\hline Losses & 1.72 & 1.02 & 2.89 & 0.87 & 2.34 & 0.89 & 7.73 \\
Loss (\%) & 22.25 & 13.20 & 24.45 & 11.25 & 17.34 & 11.51 & \\
\hline
\end{tabular}

\section{Conclusion}

Primary data were collected on area, production and other parameters to look into the demographic and socio-economic characteristics of the sampled orchardists. Average land holding size at overall level was 1.28 ha and $0.61,1.36,2.61$ ha out of which 1.06 ha and $0.57,1.20,2.15$ ha are under apple crop for marginal, small, semi-medium and medium farmers respectively.

\section{References}

Cox, D.R., 1952. Estimation by double sampling. Biometrika 39, 217-227.

Gangwar, L.S., Singh, B.B., 2007. Estimation of post harvest losses in kinnow mandarian in Punjab using a modified formula. Agricultural Economic Review 68, 315-323.

Kashyap, R., Guleria, A., 2015. Socio-economic and marketing analysis of apple growers in Mandi district of Himachal Pradesh. Journal of Hill Agriculture 6, 202-206.
Panwar, T.S., 2011. Apple production in Himachal Pradesh: an impending, crisis. Economic and Political Weekly 46, 10-12.

Prasher, R.S., Nadda, A.L., Thakur, K.S., 2000. An economic analysis of post-harvest losses of apple in Himachal Pradesh. Indian Journal of Agricultural Marketing 14, 80-88.

Sheikh, S.H., Tripathi, A.K., 2013. Socio-economic conditions of apple growers of Kashmir valley: a case study of district Anantnag. International Journal of Educational Research and Technology 4, 30-39.

Singh, R., Meenakshi, Sikka, B.K., 1990. Economics of apple production in Himachal Pradesh. Indian Journal of Agricultural Economics 163-171.

Stein, C., 1945. A two-sample test for a linear hypothesis whose power independent of the variance. Annals of Mathematical Statistics 16, 243-258. 